\begin{tabular}{|c|c|c|}
\hline$ב$ & International Journal of Current Research in & \\
\hline $\begin{array}{l}\text { EXCELLENT } \\
\text { PUBLISHERS }\end{array}$ & $\begin{array}{c}\text { Biosciences and Plant Biology } \\
\text { ISSN: 2349-8080 (Online) • Volume } 3 \text { • Number } 5 \text { (May-2016) } \\
\text { Journal homepage: } \text { www.ijcrbp.com }\end{array}$ & 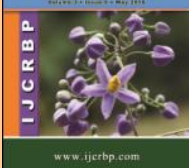 \\
\hline
\end{tabular}

\title{
Effect of 1,4-Dioxane with or without Vitamin C on Rabbits' Blood and Histology
}

\author{
A. M. Abdelhamid ${ }^{*}$, W. A. Khalil' ${ }^{1}$, A. A. M. Abdel Hamid ${ }^{2}$, Rehab F. S. A. Ismail ${ }^{1}$ and \\ Manar A. Almnsy ${ }^{1}$ \\ ${ }^{1}$ Department of Animal Production, Faculty of Agriculture, Al-Mansoura University, Egypt \\ 'Department of Histology and Cell Biology, Faculty of Medicine, Al-Mansoura University, Egypt \\ *Corresponding author.
}

\begin{abstract}
A b stract
A feeding trial for 60 days was carried out on rabbits to study the effects of 1,4-dioxane $(3.2 \mathrm{mg} / \mathrm{Kg})$ including diets with or without vitamin $\mathrm{C}(1 \mathrm{~g} / \mathrm{Kg}$ diet, as antioxidant) on their blood profile and some internal organs' histology (kidney, liver and testis). From the obtained blood results and histological examination, it could be concluded that the dietary inclusion of 1,4-dioxane was responsible for occurring a case of multiple anemia [aplastic (toxic), leukemia toxicity, and malnutrition] besides toxic hepatic and biliary tract disease, dehydration, steatorrhea, edema, myocardial infarction and/or excessive protein catabolism.
\end{abstract}

\begin{tabular}{l} 
Article Info \\
Accepted: 28 April 2016 \\
Available Online: 06 May 2016 \\
\hline Ke y w or d s \\
Biochemistry \\
Dioxane \\
Hematology \\
Histology \\
Rabbits
\end{tabular}

\section{Introduction}

Clarke and Clarke (1978) mentioned that 1,4-dioxanecontaing insecticide and acaricide (dioxathion) has the LD50 in male rats as $43 \mathrm{mg} / \mathrm{Kg}$ and in female rats as $23 \mathrm{mg} / \mathrm{Kg}$. They added that the insecticides are usually sprayed and the direct contact with organophosphorous spray is dangerous. Instances of poisoning from these compounds are due to human carelessness. Agent Orange was one of a class of color-coded herbicides that U.S. forces sprayed over the rural landscape in Vietnam to kill trees, shrubs and food crops over large areas. Agent Orange was a 50/50 mixture of two individual herbicides, 2,4-D and 2,4,5T. It remained toxic over a short period, a scale of days or weeks, and then degraded. The production of Agent Orange was halted in the 1970s, existing stocks were destroyed and it is no longer used (Dwnerychuk and Bailey, 2009). More than 43 million liters $(11,360,000$ gallons $)$ of Agent Orange were used in
Vietnam from 1965 to 1970 . In addition more than 30 million liters of Agent White, Blue, Purple, Pink and Green were also sprayed (Stellman et al., 2003; Young, 2009).

There are no accurate numbers for those who have been affected by the dioxin. However the Vietnam Red Cross estimates that up to 3 million Vietnamese have been (Fawthrop, 2004). The Vietnamese government currently provides a monthly stipend to over 200,000 Vietnamese who are believed to be affected by the toxic herbicides (Xuan, 2009). The Vietnam Association of Victims of Agent Orange is currently conducting a survey to identify those who suffer from an illness or birth defect believed to be caused by the herbicides. The U.S. Department of Veteran's Affairs has not released data on the number of U.S. veterans who received disability payments for illnesses linked to the herbicides used during the war. affected, of which 150,000 are children with birth defects 
Today the International Agency for Research on Cancer (IARC) classified 2,4-D as "possibly carcinogenic" to humans (Group 2B). 2,4-D is not Agent Orange, and the EPA has called equating 2,4-D with Agent Orange "an urban myth". Beyond agriculture, 2,4-D is also used as a common household herbicide (Community Manager (CBI), 2015). So that, the present research aimed to study the toxic effects of one of the dioxins (1,4-dioxane) with or without vitamin $\mathrm{C}$ (as antioxidant) on blood and histology on one of the very sensitive experimental animals (rabbit).

\section{Materials and methods}

\section{Experimental animals}

Eighteen V-line male rabbits newly weaned ( 25 day old) and weighing in average $450 \mathrm{~g}$ were divided randomly onto the housing wire batteries (supplied with drinkers, feeders, heater, thermometer and hygrometer to measure temperature and relative humidity of the surrounding air) at 2 rabbits/box, 3 replicates/ treatment $(=2 \times 3=6$ rabbits/treatment). Three experimental treatments, i.e. groups, were tested as follows:

- Treatment 1 (T1) or group 1' animals were fed a commercial (control) diet.

- Treatment 2 (T2) or group 2' animals were fed the same commercial (control) diet plus 1,4-dioxane (toxic diet) at level of $3.2 \mathrm{mg} / \mathrm{Kg} \operatorname{diet}(3.2 \mathrm{ppm}$ ).

- Treatment 3 (T3) or group 3' animals were fed the same commercial (control) diet plus 1,4-dioxane at level of $3.2 \mathrm{mg} / \mathrm{Kg}$ diet $(3.2 \mathrm{ppm})$ plus vitamin $\mathrm{C}$ at level of $1 \mathrm{~g} / \mathrm{Kg}$ diet (treated diet).

\section{Experimental diets preparation}

The commercial diet (control) was purchased from the local market. Vitamin $\mathrm{C}$ used in this study was Asco-Vet C $20 \%$ (powder). The liquid form of 1,4 Dioxane (Batch No. 1268, Code No. D-03532, CAS, No. 123-91-1, Assay: Min. 98\%, For Lab. use only, Made in India, Oxford Laboratory Reagent ISO: 9001-2008) was diluted in water to enable spraying small volume on the ingredients of the toxic diets.

\section{Blood analysis}

At the end of the experiment, blood samples were collected from each animal from the jugular vein into vacutainer tubes for hematological and biochemical analyses of blood by the Clinical Chemistry.

\section{Hematological parameters}

Hematological parameters including the total count of red blood cells (RBC's), white blood cells (WBC's) and their fractions (count and percentages), and platelets, packed cell volume (PCV\%), and hemoglobin $(\mathrm{Hb})$ concentration were counted or measured in fresh whole blood using fully digital hematology counter (Mindray B-C 3000 Plus, Germany).

\section{Blood serum analysis}

Other collected samples were allowed to clot and centrifuged at $3500 \mathrm{rpm}$ for 20 minutes to separate blood serum. Serum was carefully decanted into labeled tubes using serological pipettes and stored at $-20^{\circ} \mathrm{C}$ until analysis using Jenway 6051 colorimeter (U.K.) and Human and spinreact Kits for colorimetric and Fixed Kinetic methods. For tumors' indices $(\mathrm{AFP}=$ Alpha feto protein, $\mathrm{CEA}=$ Carcino embryonic antigen, and $\mathrm{PSA}=$ Prostate specific antigen) and hormones (testosterone and cortisol) measured, Siemens apparatus and kits (Germany) were used.

\section{Histological examination}

The treated animals and their controls were slaughtered, quickly dissected and their kidney, liver and testis were removed, sliced and fixed in $10 \%$ formalin solution. After $72 \mathrm{hrs}$, tissues were rinsed three times in $70 \%$ ethanol, dehydrated using a graded ethanol series and then embedded in paraffin wax. Paraffin sections were cut into 5-6 micrometers thick slices, stained with haematoxylin and eosin and examined under light microscope.

\section{Statistical analysis}

The obtained data of blood were statistically analyzed using t-test according to Sachs (1976).

\section{Results and discussion}

\section{Blood profile}

The following Tables 1 and 2 present the mean values of the hematological and biochemical parameters determined in rabbits fed the experimental diets for 60 days. There were no significant $(p>0.05)$ differences among the three treatments in all determined and calculated values, except for PDW and LDH $(p<0.05)$. Yet, the toxic diet (T2) fed rabbits reflected lower values of WBCs and its differentiations, $\mathrm{Hb}, \mathrm{RBCs}$, Hct, 
MCHC, RDW-CV, Plt., total protein and its fractions, glucose, AST, ALT, creatinine, uric acid, triglycerides, HDL, LDL $(p<0.05)$, AFP, CEA, and T.PSA than the control. The T2 caused higher MCV, MCH, RDDW-SD, MPV, PDW, $(p<0.05)$ and PCT levels than the control. But blood testosterone and cortisol levels were constant in the 3 treatments. The vitamin-C addition to the toxic diet (T3) did not ameliorate the toxic effects of dioxin on most tested criteria, even though it strengthens the toxicity syndromes.
Although both toxic (T2) and toxic plus vitamin C (T3) (dioxane-containing) diets negatively affected most blood measurements tested, dioxane-containing diets did not influence the tested hormones (testosterone nor cortisol) nor tumors' indicators [alpha feto protein (AFP), carcino embryonic antigen (CEA), and total prostatic specific antigen (T.PSA)]. That means that dioxane is not carcinogenic to rabbits and has no effect on functions of liver, kidneys, and testes.

Table 1. Mean values* of the hematological parameters determined in rabbits fed the experimental diets for 60 days.

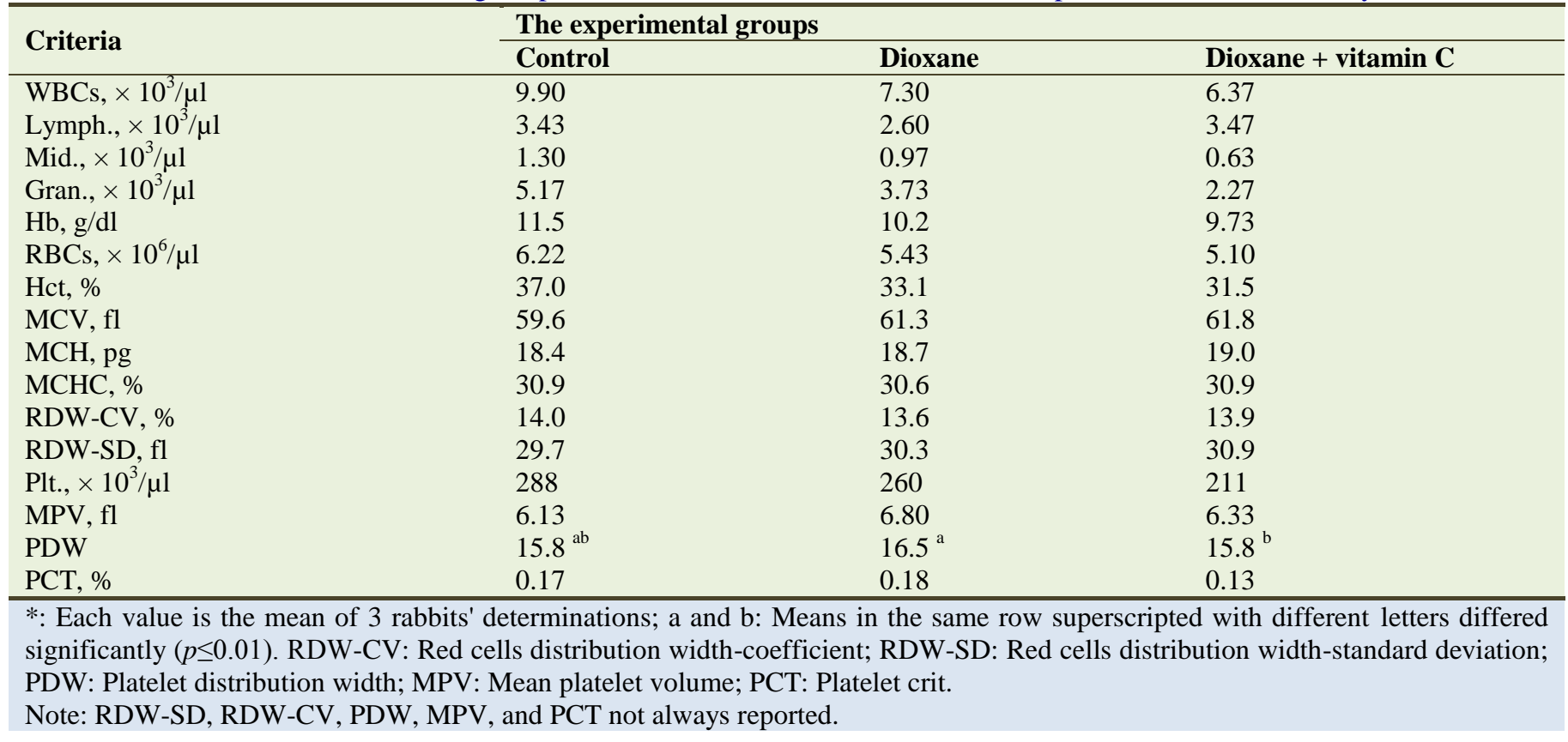

Table 2. Mean values* of the biochemical parameters determined in rabbits fed the experimental diets for 60 days.

\begin{tabular}{llll}
\hline \multirow{2}{*}{ Criteria } & The experimental groups & & Dioxane + vitamin C \\
\cline { 2 - 4 } & Control & Dioxane & 5.83 \\
\hline Total Protein, g/dl & 6.23 & 5.97 & 3.10 \\
Albumin, g/dl & 3.27 & 3.03 & 2.77 \\
Globulin, g/dl & 2.97 & 2.93 & 116 \\
Glucose, mg/dl & 103 & 101 & 44.0 \\
AST, U/l & 35.6 & 27.1 & 56.6 \\
ALT, U/l & 42.6 & 36.1 & 1.26 \\
Creatinine, mg/dl & 0.87 & 0.82 & 1.03 \\
Uric Acid, mg/dl & 1.03 & 1.00 & 55.8 \\
Cholesterol, mg/dl & 67.0 & 58.9 & 88.9 \\
Triglycerides, mg/dl & 75.6 & 63.7 & 35.3 \\
HDL, mg/dl & 33.3 & 33.1 & 5.20 \\
LDL, mg/dl & 20.5 & 13.1 & 1141 \\
LDH, U/l & $10344^{\text {a }}$ & 0.50 \\
Testosterone, $\mathrm{ng} / \mathrm{ml}$ & 0.50 & $746.3{ }^{\mathrm{b}}$ & 1.00 \\
Cortisol $(\mathrm{AM}), \mu \mathrm{g} / \mathrm{dl}$ & 1.00 & 0.50 & 0.45 \\
AFP, ng/ml & 0.55 & 1.00 & 0.30 \\
CEA, ng/ml & 0.30 & 0.50 & 0.25 \\
T. PSA, ng/ml & 0.30 & 0.20 & 0.25 \\
\hline *: Each value is the mean of 3 rabbits' determinations; a and b: Means in the same row superscripted with different letters differed
\end{tabular}




\section{Histological examination}

The histological examination of kidney of rabbits fed control diet showed normal architecture of Malpighian corpuscles (glomerulus) and renal tubules within the cortical layer of the kidney (Fig. 1). When rabbits were fed the control diet plus dioxane as a toxic substance rabbit kidney showed mild degeneration in the lining epithelial cells of renal tubules and congestion in blood capillaries in-between (Fig. 2). This effect was associated with a marked reduction uric acid concentration in blood serum (Table 2). In kidney of rabbits fed the control diet plus dioxane with vitamin $\mathrm{C}$, the previous observed degeneration was reduced with slight congestion in the glomerulus. These findings may indicate that vitamin $\mathrm{C}$ addition to diets contaminated with dioxane had impact on elimination of the toxic effect of dioxane on kidney of rabbits (Fig. 3).

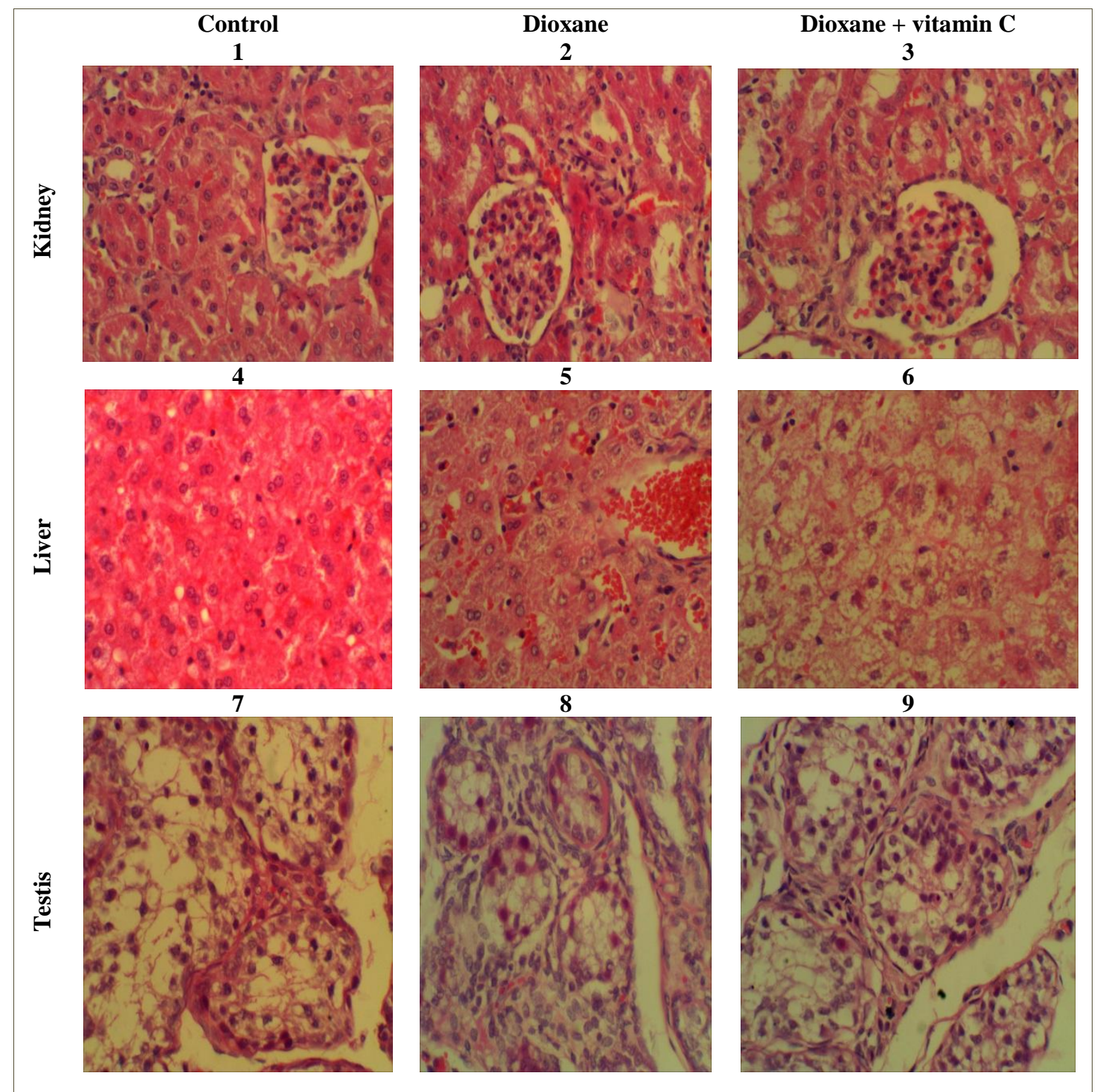

Figs. 1-9: Histology of kidney, lever and testis of rabbits fed with experimental diets for 60 days, showing moderate effect of liver. Cross section in the Kidney (1,2 and 3), Liver (4, 5, and 6) and testis (7, 8 and 9) of rabbits fed control diet, dioxane and dioxane with vitamin C, respectively (X 400).

The histological examination of liver of rabbits fed control diet showed normal histological structure of the hepatic lobules, naturally radiated hepatocyte arrangements with intact blood sinusoids (Fig. 4). Treating rabbit diets with dioxane caused several histopathological alterations including degenerated 
hepatocytes, activated Kupffer cells, some white blood cells between hepatocytes in some lobules and abnormal arrangement of blood sinusoid (Fig. 5). Addition of vitamin $\mathrm{C}$ to the diet contaminated with dioxane failed to enhance all lesions in the hepatic lobules caused by dioxane. Also these findings suggested that vitamin C addition to diets contaminated with dioxane may reduce the negative effect of dioxane on the liver functions (Fig. 6). It is of interest note that the changes in the histological structure of the liver was in relation with the trend of changes in concentration of total proteins and their fraction as well as activity of AST and ALT as a liver function parameters in blood serum of each group (Table2).

The histological examination of the testis of control rabbits revealed normal histological features but the spermatogenic layer within each seminiferous tubule was incomplete and basement membrane was thicker as well as no leydig cells were seen within the interstitial spaces, indicating undeveloped testes of the control group (Fig. 7). Results of blood serum testosterone indicated these findings, were as level of testosterone was less than 1 $\mathrm{ng} / \mathrm{ml}$ in the control group (Table 2). Rabbits fed diets plus dioxane showed increasing connective tissue within the interstitial spaces between the seminiferous tubules (stroma). Also diameter of the seminiferous tubule was lower as compared to control group (Fig. 8). Addition of vitamin $\mathrm{C}$ reduced some negative effects of dioxane on the diameters of seminiferous tubule and Stroma (Fig. 9). According to this examination, also testosterone level did not exceed above that observed in the control.

The figures given in Tables 1 and 2 are around the rabbits' values given by many authors, e.g. Merck (1976), Abdelhamid (1988a, b, c, 1989, 1990), Abdelhamid et al. (1999), Abdelhamid and Saleh (2000), Sadek (2011), Abdel-Khalek et al. (2012), Abu El-Hamd et al. (2013) and El-Medany et al. (2013). Merck (1976), who mentioned that blood $\mathrm{Hg}$ and RBCs, may be lowered by anemia whereas low WBCs may occur in toxication process.

Similar hormones (testosterone and cortisol) level in all treatments means that there was no effect of dioxane on both testis and adrenal cortex (Kutsky, 1973). Whereas Merck (1974) found that decreased Hb concentration is due to anemia, reduced RBCs count, and reduced erythrocytes volume. However, decreased WBCs number is occur in diseases of sensitivity and skin, parasites, and decreased PCV in Fe-deficient anemia. Also, lower protein concentration may occur for its loss via stomach and intestine, intoxication, skin inflammation, and disruption of the protein metabolism. Moreover, decrease of lipids may attribute to disruption of fat metabolism, low secretion rate of pancreas, hepatic cirrhosis, and malnutrition.

Soliman and Abd El Moty (1974) mentioned that aplastic anemia (the failure of the bone marrow to produce erythrocytes) may occur with some toxic substances. Also, macrocytic anemia (RBCs are larger than normal) and all other anemia are accompanied by decreased $\mathrm{Hb}$, that decreased too with leukemia toxicity, amyloid nephritis and malignant tumors. They added that leucopenia (reduced total WBCs) is responsible for weakness of the defensive mechanism of the body and indicates an unfavorable prognosis. It may occur in anemia, starvation, malnutrition and chemical toxicities. In addition, most of plasma lipids are associated with globulin and to some extend with albumin. Albumin and globulins are synthesized in the liver. Albumin may also be decreased in gastro-enteritis. Hypo-albuminemia occurs in glomerulo-nephritis, malnutrition, hepatic malignancies, hepatic necrosis, hepatic fibrosis and hepatitis. However, LDH is rather non-specific.

Latner (1975) cited that triglycerides, cholesterol and lipoproteins (LDL and HDL, the bad and good cholesterols, respectively) are synthesized in the liver. Malnutrition may decrease cholesterol level. Diets deficient in protein result in subnormal rates of synthesis of serum lipoproteins. Decreased plasma cholesterol may be correlated with the existence of steatorrhea. He added that hypobeta lipoproteinemia [decreased LDL (beta),] is associated with low levels of plasma cholesterol and triglycerides as well as glucose, hepatic and biliary tract disease, anemia and/or hyperthyroidism. Abnormal blood proteins may be due to hepatic and biliary tract disease. Decrease in total protein concentration is due to decrease in albumin and sometimes also to globulin. This may be caused by multiple myeloma, hepatic cirrhosis, diabetes mellitus, glomerulonephritis, dehydration, edema, nephritis, and/or excessive protein catabolism. Lower transaminases activity may occur in hepatic (portal) cirrhosis, biliary cirrhosis, toxic hepatitis and/or hepatic malignancy. The enzyme LDH is included in carbohydrate metabolism (catalyzes the interconversion of lactate and pyruvate), it is particularly abundant in kidney, skeletal muscle, liver, and myocardium. The activity of LDH is smaller to that of AST in case of myocardial infarction. However, cortisol is a potent inhibitor of the inflammatory reaction induced by physical, chemical and/or bacterial agents. 
In addition, Varley (1978) mentioned that AST is not specific for myocardial infarction. Whereas, LDH is especially plentiful in cardiac and skeletal muscle, liver, kidney and RBCs.

Moreover, the obtained results are confirmed with the observations and data collected on the same rabbits concerning the negative effects of feeding rabbits the contaminated diets that were responsible for very bad appearance of the face, nose and eyes, stench smell (similar to that of the dioxane itself) of the rabbits and their feces as well as their flesh (during the chemical analysis of the flesh), moderate vertebrates cord malformation (the upper (cervical) part was twisted), smaller size and weight, weakness and unbalance, increased food and water consumption followed by lower food conversion and economic efficiency as well as boneless meat and protein contents of the carcasses. The addition of vitamin $\mathrm{C}$ did not prevent these negative effects (but, to some extent, may ameliorate). Hence, the avoidance of such contaminant, in foods and drinking water, must be recognized for good rearing of the very sensitive animals such as rabbits (Abdelhamid et al., 2016).

\section{Conclusion}

It is a must to give attention to avoid such contaminant in animal foods and drinking water which could be also harmful to human being.

\section{Conflict of interest statement}

Authors declare that they have no conflict of interest.

\section{References}

Abdelhamid, A. M., 1988a. Effect of iron supplementation in rabbits and sheep diets. J. Agric. Sci. Mansoura Univ. 13, 642-650.

Abdelhamid, A. M., 1988b. Effect of dietary contamination with mercury on the performance of rabbits. Arch. Anim. Nutr. (Berlin). 38, 207-214.

Abdelhamid, A. M., 1988c. Physionutritional effects of rubratoxin-B on rabbits. Arch. Anim. Nutr. (Berlin). 38, 825-832.

Abdelhamid, A. M., 1989. Possibility of fat addition in the rabbit diets. Arch. Anim. Nutr. (Berlin). 39, 729-739.

Abdelhamid, A. M., 1990. Effect of feeding rabbits on naturally moulded and mycotoxin-contaminated diet. Arch. Anim. Nutr. (Berlin). 40, 55-63.

Abdelhamid, A. M., Saleh, M. R. M., 2000. Effect of graded levels of dietary oxalic acid on growth performance, physiological responses and histological alterations in New Zealand White rabbits. J. Agric. Sci. Mansoura Univ. 25, 4891-4903.

Abdelhamid, A. M., El-Nashar, E. M., Saleh, M. R. M., 1999. Effect of subacute ochratoxicosis- A by rabbits. Proc. $15^{\text {th }}$ Annu. Conf. Egypt. Soc. Toxicol., Alexandria. Oct. 6-7, Vol. 1. pp.71-85.

Abdelhamid, A. M., Ismail, R. F. S. A., Almnsy, M. A., 2016. An attempt to overcome dioxane toxicity by rabbits using vitamin C. Int. J. Curr. Res. Biosci. Plant Biol. 3(5), 3340 .

Abdel-Khalek, A.E., Abdelhamid, A.M., Mehrez, A.F., ElSawy, I., 2012. Growth performance, digestibility coefficients, blood parameters and carcass traits of rabbits fed biologically treated diets. J. Anim. Poult. Prod. Mansoura Univ. 3(5), 227-239.

Abu El-Hamd, M. A., Sheteifa, M. A. M., Ragab, A. A., 2013. Effect of ascorbic acid on performance and reproductive performance of does New Zealand white rabbit. J. Anim. Poult. Prod. Mansoura Univ. 4(9), 549-559.

Clarke, E.G.C., Clarke, M.L., 1978. Veterinary Toxicology. The English Language Book Society and Bailliêre Tinsall (Reprint).

Community Manager (CBI), 2015. Moderator for GMOAnswers.com. Future of GMO, Science and GMO Basics. Monday, June 22.

Dwnerychuk, W., Bailey, C., 2009. Clarity on Two Terms. http://www.warlegacies.org/Agent\%20Orange/Clarity.pdf.

El-Medany, Sh. A., El-Reffaei, W. H.., Nada, S. A., 2013. Effect of different oils on growth performance and carcass traits in growing rabbits. J. Anim. Poult. Prod. Mansoura Univ. 4(12), 733-745.

Fawthrop, T., 2004. Vietnam's War against Agent Orange. BBC News June, 14, http://news.bbc.co.uk/2/hi/health/ 3798581.stm.

Kutsky, R. J., 1973. Handbook of Vitamins and Hormons. Van Nostrand Reinhold Company, New York.

Latner, A.L., 1975. Cantarow and Trumper Clinical Biochemistry. $7^{\text {th }}$ Edn. W.B. Saunders Company, London.

Merck, E., 1974. Klinisches Labor. 12. Auflage, E. Merck, Darmstadt, Deutschland.

Merck, E., 1976. Labordiagnostik in der Tiermedizin. Diagnostica Merck, Deutschland.

Sachs, L., 1976. Statistische Methoden, Ein Soforthelfer, Dritte, neubearbeitete Auflage, Springer- Verlag, Berlin.

Sadek, A.M.A., 2011. Studies in feeding rabbits. Ph.D. Thesis, Faculty of Agriculture, Al-Mansourah University.

Soliman, M.K., Abd El Moty, I., 1974. A Modern Approach to Veterinary Clinical and Laboratory Diagnosis. The Scientific Book Centre, Cairo. 747p.

Stellman, J.M., Steven, D., Stellman, S.D., Christian, R., Weber, T., Tomasallo, C., 2003. The extent and pattern of usage of agent orange and other herbicides in Viet Nam. Nature. 422, 682.

Varley, H., 1978. Practical Clinical Biochemistry. $4^{\text {th }}$ Edn. Reprinted, Arnold-Heinemann Publishers (India) Private Limited. 
Xuan, N.Q., 2009. Statement by Ambassador Ngo Quang Xuan to the House Subcommittee of Asia, Pacific and Global Environment. June: Page 3. http://www. internationalrelations.house.gov/111/xua060409.pdf.
Young, A., 2009. The History, Use and Disposition and Environmental Fate of Agent Orange. Springer, Science and Business Media, New York.

\section{How to cite this article:}

Abdelhamid, A. M., Khalil, W. A., Abdel Hamid, A. A. M., Ismail, R. F. S. A., Almnsy, M. A., 2016. Effect of 1,4-dioxane with or without vitamin $\mathrm{C}$ on rabbits' blood and histology. Int. J. Curr. Res. Biosci. Plant Biol. 3(5), 113-119. doi: http://dx.doi.org/10.20546/ijcrbp.2016.305.018 